Jurnal Pena Sains Vol. 5, No. 1, April 2018

p-ISSN: 2407-2311

e-ISSN: 2527-7634

\title{
THE DEVELOPING OF LEARNING MEDIA BASED ARTICULATE STUDIO'13 IN ASSESSMENT COURSE AT BIOLOGY EDUCATION STUDY PROGRAM
}

\author{
Hepta Bungsu Agung Jayawardana ${ }^{1}$ and Mochammad Maulana Trianggono² \\ ${ }^{1}$ Biology Education Study Program, Faculty of Mathematics and Natural Science Education, IKIP PGRI Jember \\ Jember, 68121, Indonesia \\ hepta2011@gmail.com \\ ${ }^{2}$ Biology Education Study Program, Faculty of Mathematics and Natural Science Education, IKIP PGRI Jember \\ Jember, 68121, Indonesia \\ maulanafisika09@gmail.com
}

\begin{abstract}
The purpose of the study is developing articulate studio ' 13 based learning expert validation through the media and examine the effect on the student learning outcomes. The participants include 48 students of biology education IKIP PGRI Jember with One Shot-Case Study design. The data is analyzed descriptively qualitative. The result of the validation is categorized, the feasible learning activity is good, the student's response is well classified and learning outcomes is complete. The conclusion of this study is learning media based articulate studio ' 13 can improve student motivation and learning outcomes.
\end{abstract}

Keywords: Articulate studio '13, Learning outcomes, Learning media 


\section{Introduction}

Science and technology continue to evolve rapidly contributing positively to the world of education. This can be seen in a variety of school and college levels that may involve technology in the teaching and learning process, a kind of laptop usage; LCD; and even multimedia room. The lecturer is required not only to provide the latest information but also packaging the information was expected to be more creative and innovative in order that students enjoy attending and not lazy in learning. Sanjaya (2009) mentions that educators need learning media precise and easy to understand so that the student is not wrong and easier to capture the content of the lecture material itself.

The media is the vehicle dealer or retailer learning information message (Djamarah and Zain, 2013). If the media is a source of learning, then broadly defined media with humans, things, or events that lets students gain knowledge and skills. The difficulty of the material to be delivered to students can be simplified with the help of the media, especially in the field of science that the concept is abstract. Media according to Arsyad (2011) media or medius (Greek) which means middle, intermediate, or introduction. According to the Association of Education Communication Technology, all forms and channels used to deliver the message or information. Learning media is a part which cannot be separated in the process of teaching and learning, for delivering or delivering messages of teaching.

The media generally are human, material or events that build conditions that make students to acquire the knowledge, skills or attitudes (Gerlach and Eli, in Arsyad, 2011).
Table 1 below is media types according to Arsyad (2011) that cite from Leshin, Pollock, and Reigeluth.

Tabel 1 Jenis Media

\begin{tabular}{lll}
\hline $\begin{array}{c}\text { Base Type of } \\
\text { Media }\end{array}$ & & \multicolumn{1}{c}{ Example } \\
\hline A. Human & 1. & Peer \\
& 2. & Teacher \\
& 3. & Specialist \\
& 4. & Roleplay \\
B. Print & 1. & Book \\
& 2. & Journal \\
& 3. & Magazine \\
& 4. & Encyclopedia \\
C. Visual & 1. & Chart \\
& 2. & Graph \\
& 3. & Map \\
D. Audio Visual & 1. & Video \\
& 2. & Film \\
& 3. & Animation \\
& 4. & Television \\
& & \\
E. Computer & 1. & Interactive \\
& 2. & Animation \\
& 3. & Social Mased \\
\hline
\end{tabular}

According to Honey (2011) and Connolly (2012), there are several criteria that become the focus in the selection of the media for learning, among other characteristics of students, learning objectives, learning materials, procurement of media. Based on these things, then the addition of multimediabased learning that is Articulate studio ' 13. Software Articulate studio ' 13 is the artificial software Global Incorporation of the country the USA is devoted to designing ICT-based learning media.

How to obtain the software by downloading free on his official website www.articulate.com. In the installation package of the software is not accompanied by a Tutorial of use just like any other educational software. The tutorial is available only online (connected 
to the internet) and in one of the software packages that will cater to this after 88.4 MB installed on the computer that Windows-powered: Windows XP, Vista, Seven, or Windows 8 or the latest Windows 10.

According to Ghozali (2016), the articulate program has advantages i.e. smart brain ware simple interactive tutorial with procedures through a template that can be published online or offline so as to allow a user to format it in the form of the Web Personal, CD, Word Processing, and Learning Management System (LMS).

Articulate studio ' 13 contains three programs. The first program is the Articulate Presenter, similar programs with Microsoft power point that serves to present the data, images, video, and animation. However, in the program, there is additional presenters articulate feature inserts a profile which can be either a picture or cartoon characters with diverse professions.

Second, Articulate Quiz maker is the most exciting programs in the package articulate studio ' 13 , because this special program is used to create quizzes, question, training, and even a test or exam though web-based. Problems created by this program can be used separately with other programs or used in learning elearning (Learning Management Systems, LMS) that already exists. Articulate quiz maker provides various types of matter, both the nature of the survey (without assessment) as well as the question of who will be evaluated so that determine the outcome score/level (grade). With the variegated types of multiple choice question, essay, ask even drawing, the user can select in accordance with its purpose. This becomes its own advantages given in addition not found in other programs, users are also very easy to correct the problem and work results can be directly evaluated.
Finally, Articulate Engage, the interactive multimedia programs with a wide range of features, one of the most interesting feature is the preview it looks very easy to operate and not boring. This program can also be inserted some video learning at once including various types of animation, in addition, there is also a subtopic of identity that can display the characters in the cartoon either media owners as well as the actual image.

Student assessment courses are courses that must be taken by all students on the Biology education courses. The content on this subject covers all aspects, not only the concept but also the process and the way the reporting of assessment and evaluation in learning. Speaking of evaluation in the learning of cognitive, affective and psychomotor. Therefore, students often have difficulty in capturing the material presented by lecturers in addition because the material is too dense, the way a lot of his lecture lecturer delivering so many students whose value falls even had to repeat, even though this subject other than mandatory as well as the prerequisites for implementing the practice of field experience.

During this lecture in IKIP PGRI Jember in delivering courses student assessment only learning to use media in the form of power point presented in lectures by his old, these things tend to make students not interested, bored and even lazy to learn (Utama, Kentjananingsih, \& Rahayu, 2014). In accordance with the above exposure, then the researchers looked at the need to do a research on "the development of learning Media based, Articulate Studio ' 13 Courses student assessment In Biology education courses". 


\section{Research Methods}

This type of research is research development with a research design One Shot-Case Study (Sugiyono, 2010). The design is as shown in table 2, the sample was given preferential treatment in advance in the form of learning to use learning media-based Articulate Studio '13, and after being given the treatment than do the ultimate test.

Table 2 Design research of One ShotCase Study

\begin{tabular}{cc}
\hline Treatment & Observation \\
\hline $\mathrm{X}$ & $\mathrm{O}$ \\
\hline
\end{tabular}

As for the design of the learning media development in this research follows the model $4 \mathrm{~d}$ (Rosidi, 2015) modified by the researcher. Next media developed learning activities implemented in learning on campus.

At the end of the meeting, the subject of the research was given a question form. Question form was constructed to obtain findings of learning outcomes through the development of learning media based Articulate Studio ' 13: technology skills improvement, confidence, self-reflection, and a willingness to continue to develop. Now using the Likert scale with three alternative choices (interested, less interested, and not interested). Student responses were analyzed descriptively.

The subject is a student who attended courses student assessment. Implementation media planned even semester academic year 2016/2017. The place of research carried out in the Bio Campus III 2 IKIP PGRI Jember.

Based on the research questions have been posted at the start, the variables in the study are: First, Feasibility of mediabased Articulate Studio ' 13. Second, learning implementation to use mediabased Articulate Studio ' 13. Third, student responses in learning activities using the media-based Articulate Studio ' 13. Lastly, student learning outcomes after following the course media-based Articulate Studio ' 13. Data analysis uses qualitative and descriptive statistics for revealing the circumstances as it is. A descriptive qualitative study on using the formula (1)

$$
\mathrm{p}=\frac{\mathrm{f}}{\mathrm{N}} \times 100 \%
$$

$$
\begin{aligned}
& \text { Description: } \\
& \mathrm{p}=\quad \begin{array}{l}
\text { the percentage of the number of students } \\
\text { who do not complete the process of }
\end{array} \\
& \text { learning subjects in student assessment } \\
& \text { the number of students who got the value } \\
& \text { of the results of the study }(55<\mathrm{x}<70), \\
& \mathrm{N}=\quad \begin{array}{l}
\text { and } \\
\text { the number of students overall. }
\end{array}
\end{aligned}
$$

Indicators of achievement of the targets for the improvement of the learning results in $90 \%$ of the students are already getting the value of classical learning results $\geq 70$.

\section{Result and Discussion}

Table 3 shows the results of the development of learning media based Articulate Studio ' 13 with some revision of the validator.

Table 3 The Results of expert judgment validation

\begin{tabular}{clll}
\hline No. $\begin{array}{l}\text { This type } \\
\text { of revision }\end{array}$ & $\begin{array}{c}\text { Before the } \\
\text { revised }\end{array}$ & $\begin{array}{l}\text { After the } \\
\text { revised }\end{array}$ \\
\hline 1. & $\begin{array}{l}\text { Audio, not } \\
\text { clear }\end{array}$ & $\begin{array}{l}\text { Insufficient } \\
\text { audio }\end{array}$ & $\begin{array}{l}\text { The use of } \\
\text { customized } \\
\text { audio with the } \\
\text { quality of the } \\
\text { speakers }\end{array}$ \\
2. The letter & $\begin{array}{l}\text { The use of a } \\
\text { typeface } \\
\text { is not clear font }\end{array}$ & $\begin{array}{l}\text { The use of a } \\
\text { typeface and } \\
\text { font color is } \\
\text { obvious }\end{array}$ \\
\hline
\end{tabular}




\begin{tabular}{llll}
\hline No. & $\begin{array}{l}\text { This type } \\
\text { of revision }\end{array}$ & $\begin{array}{l}\text { Before the } \\
\text { revised } \\
\text { color not } \\
\text { clear } \\
\text { The }\end{array}$ & $\begin{array}{c}\text { After the } \\
\text { revised }\end{array}$ \\
\hline 3. & $\begin{array}{l}\text { The } \\
\text { submission } \\
\text { of a } \\
\text { concept is } \\
\text { not clear } \\
\text { Color }\end{array}$ & $\begin{array}{l}\text { less obvious } \\
\text { animation }\end{array}$ & $\begin{array}{l}\text { The material } \\
\text { in the clear } \\
\text { animation }\end{array}$ \\
image & $\begin{array}{l}\text { The } \\
\text { quality for }\end{array}$ & $\begin{array}{l}\text { selection of } \\
\text { color } \\
\text { less }\end{array}$ & $\begin{array}{l}\text { Color images with } \\
\text { used has a } \\
\text { size of pixels } \\
\text { that seem }\end{array}$ \\
& sizes & obvious \\
& & \\
\hline
\end{tabular}

Learning media based articulate studio '13 developed experience several times revised. Revisions made on parts of the output sound (audio), the look of the letter, the contents of the concept and the quality of the color image shown. Learning media expert who was appointed as the validator says that media based articulate studio ' 13 developed will be valid if the fourth-the revised section has been revised.

The revised media according to the validator is already arguably worthy of use in learning because the validator validates the very valid. The component sounds, letters and the suitability of the concept is an important component of learning at the time will affect the level of ease in understanding the content of student learning and the learning objectives have been determined in advance. Delivery of material through visual and verbal messages contribute to high in helping students retain information into short-term memory or memory work. Thus, the verbal message must be supported with an appropriate visual message as a binary coding theory by Paivio (1986). In other words, the difficulty in understanding the verbal message students during the learning can be overcome with a visual message.
The implementation data gained from learning the observations by two observers, made during two sightings with the observation sheet already provided and the observations of two people the observer can be seen at Table 4 .

Based on table 4, the implementation of the study at the first meeting is already said to be good despite the fact there is still insufficient recognition in terms of student motivation, time management, how professors invite students to conclude learning together as well as the level of enthusiasm of the students.

Discrepancies in the management of the planned time with practice in the classroom because students still need time to get to know the use of media-based articulate studio ' 13 who have never given during lectures. Almost the whole of the students initially feels the newness serving material with the media. However, several students are focus on the content or material is submitted through the media. Lecturer is not enough just by presenting the material without giving recognition and supervision are given first through an easy explanation is accepted by the student.

The number of students is relatively a lot of it is possible to seize the time to give explanations one by one. Thus, the effectiveness of the use of time in the process of the lecture done by forming study groups, the role of peers in learning can optimize performance and understanding by sharing knowledge, asking and discussion to solve problems. Small groups to train students to care and working together achieve a particular goal. This turned out to be very helpful to students in understanding the material presented using media based articulate studio ' 13 with small groups. 
Table 4 Teaching Implementation Session 1

\begin{tabular}{|c|c|c|c|c|c|}
\hline \multirow{2}{*}{ No. } & \multirow{2}{*}{ Aspects of the observed } & \multicolumn{4}{|c|}{ Assessment } \\
\hline & & P1 & Category & P2 & Category \\
\hline \multirow[t]{3}{*}{ I. } & INTRODUCTION & & & & \\
\hline & a. motivating students & 3 & $\mathrm{C}$ & 3 & $\mathrm{C}$ \\
\hline & b. explaining a learning product & 3 & $\mathrm{C}$ & 4 & B \\
\hline \multirow[t]{7}{*}{ II. } & MAIN ACTIVITY & & & & \\
\hline & a. the learning material presented & 3 & $\mathrm{C}$ & 4 & B \\
\hline & b. Developing student groups & 3 & $\mathrm{C}$ & 4 & B \\
\hline & $\begin{array}{l}\text { c. guiding the initial training to conduct activities in } \\
\text { the quiz }\end{array}$ & 3 & $\mathrm{C}$ & 4 & B \\
\hline & $\begin{array}{l}\text { d. getting around guide discussion and checking the } \\
\text { implementation of the discussion and give } \\
\text { feedback in the form of a question. }\end{array}$ & 3 & $\mathrm{C}$ & 4 & B \\
\hline & $\begin{array}{l}\text { e. the rounds checking implementation discussions } \\
\text { and provide feedback to write down the results of } \\
\text { the discussions on the answer sheet in the quiz that } \\
\text { you have prepared. }\end{array}$ & 3 & $\mathrm{C}$ & 4 & B \\
\hline & $\begin{array}{l}\text { f. guiding the operations of the group discussion } \\
\text { results presentation }\end{array}$ & 3 & $\mathrm{C}$ & 4 & B \\
\hline \multirow[t]{3}{*}{ III. } & CLOSING & & & & \\
\hline & a. drawing up conclusions the results of the study & 2 & $\mathrm{~K}$ & 3 & $\mathrm{C}$ \\
\hline & b. the reflection learning & 3 & $\mathrm{C}$ & 4 & B \\
\hline IV. & $\begin{array}{l}\text { MANAGEMENT OF TIME IN EACH STEP OF } \\
\text { THE LEARNING }\end{array}$ & 2 & K & 3 & $\mathrm{C}$ \\
\hline \multirow[t]{3}{*}{ V. } & $\begin{array}{l}\text { OBSERVATIONS OF THE ATMOSPHERE OF } \\
\text { THE CLASSROOM }\end{array}$ & & & & \\
\hline & - Students enthusiastically & 2 & K & 3 & $\mathrm{C}$ \\
\hline & - Enthusiastic teachers & 3 & $\mathrm{C}$ & 4 & B \\
\hline
\end{tabular}

Table 5 Teaching Implementation Session 2

\begin{tabular}{|c|c|c|c|c|c|}
\hline \multirow{2}{*}{ No. } & \multirow{2}{*}{ Aspects of the observed } & \multicolumn{4}{|c|}{ Assessment } \\
\hline & & P1 & Category & $\mathbf{P 2}$ & Category \\
\hline \multirow[t]{3}{*}{ I. } & INTRODUCTION & & & & \\
\hline & a. motivating students & 4 & B & 4 & B \\
\hline & b. explaining a learning product & 4 & B & 4 & B \\
\hline \multirow[t]{7}{*}{ II. } & MAIN ACTIVITY & & & & \\
\hline & a. the learning material presented & 4 & B & 4 & B \\
\hline & b. Developing student groups & 4 & B & 4 & B \\
\hline & $\begin{array}{l}\text { c. guiding the initial training to conduct activities in } \\
\text { the quiz }\end{array}$ & 3 & $\mathrm{C}$ & 3 & $\mathrm{C}$ \\
\hline & $\begin{array}{l}\text { d. getting around guide discussion and checking the } \\
\text { implementation of the discussion and give feedback } \\
\text { in the form of a question. }\end{array}$ & 4 & B & 4 & B \\
\hline & $\begin{array}{l}\text { e. the rounds checking implementation discussions and } \\
\text { provide feedback to write down the results of the } \\
\text { discussions on the answer sheet in the quiz that you } \\
\text { have prepared. }\end{array}$ & 4 & B & 4 & B \\
\hline & $\begin{array}{l}\text { f. guiding the operations of the group discussion } \\
\text { results presentation }\end{array}$ & 3 & $\mathrm{C}$ & 4 & B \\
\hline III. & $\begin{array}{l}\text { CLOSING } \\
\text { a. drawing up conclusions the results of the study }\end{array}$ & 4 & B & 4 & B \\
\hline
\end{tabular}




\begin{tabular}{|c|c|c|c|c|c|}
\hline \multirow{2}{*}{ No. } & \multirow{2}{*}{ Aspects of the observed } & \multicolumn{4}{|c|}{ Assessment } \\
\hline & & P1 & Category & $\mathbf{P 2}$ & Category \\
\hline \multirow[b]{2}{*}{ IV. } & b. the reflection learning & 4 & $\overline{\mathrm{B}}$ & 4 & $\overline{\mathrm{B}}$ \\
\hline & $\begin{array}{l}\text { MANAGEMENT OF TIME IN EACH STEP OF } \\
\text { THE LEARNING }\end{array}$ & 3 & $\mathrm{C}$ & 4 & B \\
\hline \multirow[t]{4}{*}{ V. } & $\begin{array}{l}\text { OBSERVATIONS OF THE ATMOSPHERE OF } \\
\text { THE CLASSROOM }\end{array}$ & & & & \\
\hline & a. Students enthusiastically & 3 & $\mathrm{C}$ & 4 & B \\
\hline & b. Enthusiastic Teachers & 4 & $\mathrm{~B}$ & 4 & $\mathrm{~B}$ \\
\hline & Reliability & \multicolumn{4}{|c|}{$96 \%$} \\
\hline
\end{tabular}

Based on table 5, seen an increase in the learning implementation. Students are motivated and enthusiastic during the learning process; however, observers suggest that still pays attention to the management of time in every step of the study. At the second meeting, attention is very high when students enter into the activities of the quiz. Clarity in guiding activities should come with a written description so that trained students do activities systematically in accordance with the instructions. In addition, the instructions in writing are very important in saving time for process supervision of students because of them as a compliment the explanation lecturer orally. There are times when the voice of the lecturer did not reach out to all students so that the process of restarting the repeating explanation would lead to a waste of time. Evaluation online increases the motivation and enthusiasm of the students so that this activity increases the curiosity of the students.

Student responses were given to question form 48 student after finished study. Table 6 shows some students look less interested in learning with the use of media-based Articulate Studio' 13 because the student feels the media is not too recently, in addition, there are also factors It is likely that these students never get to know the media through the internet but only as never seen yet come to realize in the making and it is used in the course evaluation. The disinterest, in the end, affects students understanding against the material presented.

Table 6 Student Responses

\begin{tabular}{|c|c|c|c|c|}
\hline No. & Question Description & \multicolumn{3}{|c|}{ Valuation Opinions } \\
\hline \multirow[t]{7}{*}{ A. } & How is your opinion on the following components? & Interested & Less Interested & Not Interested \\
\hline & & $\mathrm{F}$ & $\mathrm{F}$ & $\mathrm{F}$ \\
\hline & 1. Material/content & 46 & 2 & 0 \\
\hline & 2. Learning Media & 48 & 0 & 0 \\
\hline & 3. Quiz & 48 & 0 & 0 \\
\hline & 4. An atmosphere of learning & 45 & 3 & 0 \\
\hline & 5. How to teach a lecturer & 47 & 1 & 0 \\
\hline \multirow[t]{6}{*}{ B. } & The following components do you feel new? & New & Less New & Not New \\
\hline & & $\mathrm{F}$ & $\mathrm{F}$ & $\mathrm{F}$ \\
\hline & 1. Learning Media & 47 & 1 & 0 \\
\hline & 2. Quiz & 48 & 0 & 0 \\
\hline & 3. An atmosphere of learning & 47 & 1 & 0 \\
\hline & 4. How to teach a lecturer & 46 & 2 & 0 \\
\hline \multirow[t]{2}{*}{ C. } & Are you easily understand the following components? & Clear & Less Obvious & Not Clear \\
\hline & & $\mathrm{F}$ & $\mathrm{F}$ & $\mathrm{F}$ \\
\hline
\end{tabular}




\begin{tabular}{|c|c|c|c|c|}
\hline No. & Question Description & \multicolumn{3}{|c|}{ Valuation Opinions } \\
\hline & 1. Language teaching material in university students & 47 & 1 & 0 \\
\hline & 2. The material on the learning Media & 48 & 0 & 0 \\
\hline & 3. Quiz & 47 & 1 & 0 \\
\hline & 4. How to teach a lecturer & 46 & 2 & 0 \\
\hline \multirow[t]{3}{*}{ D. } & How does interest you to follow this kind of learning on & Interested & Less Interested & Not Interested \\
\hline & the learning activities the next over other subjects? & $\mathrm{F}$ & $\mathrm{F}$ & $\mathrm{F}$ \\
\hline & & 48 & 0 & 0 \\
\hline \multirow[t]{4}{*}{ E. } & & Clear & Less Obvious & Not Clear \\
\hline & & $\mathrm{F}$ & $\mathrm{F}$ & $\mathrm{F}$ \\
\hline & $\begin{array}{l}\text { How does the explanation lecturer upon the learning } \\
\text { activities? }\end{array}$ & 48 & 0 & 0 \\
\hline & $\begin{array}{l}\text { How does the guidance of a lecturer at the time working } \\
\text { on the quiz in the learning media-based Articulate Studio } \\
\text { ' } 13 \text { ? }\end{array}$ & 48 & 0 & 0 \\
\hline
\end{tabular}

F: The Number of Students Frequency

Nevertheless, the table above shows the whole learning process is categorized very interesting and clear, while against the media learning, most students assume it is new material and it was clear and it looks very interesting so being able to increase the motivation of learning students.

Based on Table 7 shows that there is only one person who has not reached students mastery learning. This occurs as a result of less motivation, it makes the student pay attention to learning. In addition, the students are less actively involved in the discussion in a small group of friends in his group has even offered to help if having difficulty. In this case, the Professor need to give full attention towards students with such characters by selecting the right approach in order to guide the students during the student has not mastered the learning. Supervision is also required for students with difficulties experienced during the learning process. In addition to the two students, as many as 46 students have reached the criteria of mastery learning. Associated students who have not reached mastery learning, the student must follow a remedial program.
Table 7 Student Learning Outcomes

\begin{tabular}{|c|c|c|c|}
\hline Students & $\begin{array}{l}\text { Mid } \\
\text { Test }\end{array}$ & $\begin{array}{c}\text { Final } \\
\text { Test }\end{array}$ & Final Value \\
\hline 1 & 58 & 90 & 83.1 \\
\hline 2 & 39 & 97.5 & 79.8 \\
\hline 3 & 61 & 95 & 85.95 \\
\hline 4 & 31 & 92.5 & 79.7 \\
\hline 5 & 48 & 100 & 84.85 \\
\hline 6 & 33 & 65 & 68.1 \\
\hline 7 & 31 & 87.5 & 76.7 \\
\hline 8 & 59 & 97.5 & 85.55 \\
\hline 9 & 68 & 100 & 91.6 \\
\hline 10 & 47 & 95 & 84.15 \\
\hline 11 & 60 & 95 & 85.75 \\
\hline 12 & 64 & 92.5 & 86.3 \\
\hline 13 & 75 & 65 & 79.75 \\
\hline 14 & 71 & 85 & 84.95 \\
\hline 15 & 58 & 100 & 85.6 \\
\hline 16 & 22 & 85 & 74.4 \\
\hline 17 & 7 & 85 & 69.9 \\
\hline 18 & 28 & 99 & 81.3 \\
\hline 19 & 34 & 87.5 & 75.3 \\
\hline 20 & 47 & 92.5 & 80.9 \\
\hline 21 & 56 & 95 & 83.2 \\
\hline 22 & 72 & 97.5 & 89.9 \\
\hline 23 & 47 & 70 & 71.15 \\
\hline 24 & 72 & 92.5 & 90.9 \\
\hline 25 & 64 & 100 & 88.05 \\
\hline 26 & 49 & 92.5 & 79.55 \\
\hline 27 & 37 & 95 & 81.15 \\
\hline 28 & 44 & 90 & 78.55 \\
\hline 29 & 51 & 95 & 84.7 \\
\hline 30 & 44 & 95 & 83.3 \\
\hline 31 & 64 & 90 & 82.8 \\
\hline 32 & 65 & 70 & 77 \\
\hline 33 & 40 & 100 & 82.25 \\
\hline 34 & 78 & 100 & 91.1 \\
\hline 35 & 28 & 75 & 70.1 \\
\hline
\end{tabular}




\begin{tabular}{cccc}
\hline Students & $\begin{array}{c}\text { Mid } \\
\text { Test }\end{array}$ & $\begin{array}{c}\text { Final } \\
\text { Test }\end{array}$ & Final Value \\
\hline 36 & 55 & 82.5 & 79.5 \\
37 & 43 & 60 & 73.85 \\
38 & 30 & 95 & 80.25 \\
39 & 31 & 80 & 71.7 \\
40 & 42 & 95 & 81.15 \\
41 & 25 & 100 & 81.5 \\
42 & 38 & 80 & 76.1 \\
43 & 58 & 92.5 & 80.6 \\
44 & 62 & 95 & 88.9 \\
45 & 51 & 90 & 83.2 \\
46 & 25 & 95 & 79.5 \\
47 & 55 & 90 & 78.5 \\
48 & 49 & 97.5 & 85.05 \\
\hline
\end{tabular}

\section{Conclusions and Suggestions}

Based on the explanation and discussion of results of research-based learning media development articulate studio '13 courses student assessment shows that the development of this medium can attract students' motivation and completes lectures evaluation of the results of the study on biology education courses.

Suggestions for similar researchers in developing instructional media to pay more attention to development time and the availability of experts in their fields as it affects the quality of the media. In addition, learning media-based articulate studio ' 13 can be used as an alternative choice for learning.

\section{Reference}

Arikunto, S. (2010). Dasar-dasar Evaluasi Pendidikan. Jakarta: Bumi Aksara.

Arsyad, A. (2011). Media Pembelajaran. Jakarta: PT. Raja Grafindo Persada.

Connolly, T, M., Boyle, E, A., MacArthur, E., Hainey, T., Boyle, J, M. (2012). A Systematic Literature Review of Empirical Evidence on
Computer Games and Serious Games. Computers \& Education. Vol.59:661-686.

Djamarah, S, B. dan Zain, A. (2013). Strategi Belajar Mengajar. Jakarta: Rineka Cipta.

Ghozali, F, A., Rusimamto, P, W. (2016). Pengembangan Media Pembelajaran Berbasis Articulate Studio'13 Kompetensi Dasar Arsitektur dan Prinsip Kerja Fungsi Setiap Blok PLC di SMK Negeri 1 Sampang. Jurnal Pendidikan Teknik Elektro. Vol.05, No.01, Tahun 2016:223228.

Honey, M, A., and Hilton, M, L. (2011). Learning Science Through Computer Games and Simulations. The National Academies Press. Washington DC Jong, de, T., Specht, M, \& Koper, R. (2008). Contextualised Media for Learning. Educational Technology \& Society. 11(2):4153.

Nouri, H., Shahid, A. (2005). The Effect of Powerpoint Presentations on Student Learning and Attitudes. Global Perspectives on Accounting Education. Vol.2:5373.

Paivio, A. (1986). Mental representations: A dual coding approach. New York: Oxford University Press.

Ratumanan, Gearson Tanwey. 2006. Evaluasi Hasil Belajar yang Relevan dengan Kurikulum Berbasis Kompetensi. Surabaya: Unesa University Press.

Utama, C., Kentjananingsih, S., \& Rahayu, Y. S. (2014). Penerapan Media Pembelajaran Biologi SMA dengan Menggunakan Model Direct Instruction Untuk Meningkatkan Hasil Belajar Siswa. Jurnal Pena Sains, 1(1), 29-39. 
Salmiyati. (2007). Implementasi Teknologi Multimedia Interaktif dalam Pembelajaran Konsep Saraf untuk Meningkatkkan Pemahaman dan Retensi Siswa. Tesis. Program Pascasarjana UPI Bandung.

Sanjaya, W. (2009). Perencanaan dan Desain Sistem Pembelajaran. Jakarta: Kencana Perdana Media Group.

Sugiyono. (2010). Metode Penelitian Kuantitatif Kualitatif dan R\&D. Bandung: Alfabeta.

Taufik, M. (2011). Pengembangan Lembar Kegiatan Siswa Sebagai Pendukung Pembelajaran Menggunakan Media Simulasi Phet dan Implementasinya. Tesis.
Program Pascasarjana UNESA Surabaya. 